\title{
Chemical, Hydrological and Climatological Properties of Lake Agmon, Hula Valley (Israel), (1994-2006)
}

\author{
Moshe Gophen*, Moshe Meron, Yosef Tsipris, Valerie Orlov-Levin, Mordechay Peres \\ Migal, Scientific Research Institute, Kiryat Shmone, Israel \\ Email: "Gophen@Migal.org.il
}

Received 25 November 2015; accepted 9 January 2016; published 12 January 2016

Copyright (C) 2016 by authors and Scientific Research Publishing Inc.

This work is licensed under the Creative Commons Attribution International License (CC BY).

http://creativecommons.org/licenses/by/4.0/

c) (i) Open Access

\begin{abstract}
The first decade of monitoring program in Lake Agmon (Hula Valley, Northern Israel) is summarized. The presented part of the program include: water discharges, physico-chemical (pH, EC, Temperature) and chemical parameters (TP, TN, TDN, TDP, $\mathrm{NO}_{3}, \mathrm{NH}_{4}, \mathrm{SO}_{4}$, TDS, TSS,). It was found that Nitrogen concentrations decline from north to south and the opposite for Phosphorus. Resulting of re-suspension by wind direction of western-southern-eastern and averaged maximal velocities of $9-10 \mathrm{~m} / \mathrm{s}$ is suggested. De-nitrification and particles sedimentation emphasize Lake Agmon as a sink for Nitrogen. Sulfate-Carbonates association and the production of precipitated Gypsum $\left(\mathrm{CaSO}_{4}\right)$ highlight the sink property of Lake Agmon. Nevertheless Sulfate removal by the Lake Agmon hydrological system is significant.
\end{abstract}

\section{Keywords}

Agmon, Hula, Chemical, Hydrological, Climatological, Properties

\section{Introduction}

Prior to the 1950's, the Hula Valley was mostly (6500 ha) covered by old Lake Hula (1300 ha) and swampy wetlands. This area was not cultivated, malaria was common and water loss existed by Evapo-Transpiration. Three rivers, Hatzbani, Banyas and Dan, flow southern down from Mount Hermon joint together with several other streams, forming the Jordan River. The Jordan River contributes about $63 \%$ of the downstream Lake Kinneret's water budget, but $70 \%$ of total nutrient inputs, of which over $50 \%$ originate in the Hula Valley region, the valley and slopes on both sides (east and west). During the 1950's, 6500 ha of natural wetland and old Lake

\footnotetext{
${ }^{*}$ Corresponding author.

How to cite this paper: Gophen, M., Meron, M., Tsipris, Y., Orlov-Levin, V. and Peres, M. (2016) Chemical, Hydrological and Climatological Properties of Lake Agmon, Hula Valley (Israel), (1994-2006). Open Journal of Modern Hydrology, 6, 8-18. http://dx.doi.org/10.4236/ojmh.2016.61002
} 
Hula were drained, and converted to agricultural use which served as an income source for regional residents. Initially the drained area was successfully cultivated, agricultural products were economically produced and the nutrient flux into Lake Kinneret did not threaten its water quality. However, as a result of inappropriate irrigation and agricultural methods desertification processes developed, the peat soil quality was damaged, consolidated and destructed, accompanied by heavy dust storms subsidence of soil surface, drainage canal were blocked, underground fires were enhanced, and quite often outbreaks of rodent population. These deteriorated factors damaged agricultural crops, reduced yields and returns. In large parts of the drained area agriculture lost its economic viability and therefore became uncultivated causing an increasing of threat to water quality in Lake Kinneret from exceeded nutrient fluxes.

A reclamation project (Hula Reclamation Project, HRP) was consequently implemented, aimed at reducing the nutrient fluxes from the Hula peat soil together with economical utilization of the land through a partial shift from agriculture to eco-tourism usage [1] [2]. This concept is based on anthropogenic changes to the environment, combined with introduction of natural plants and reconstruction of the hydrological-drainage structure of the entire valley. Among the objectives of the HRP was enhancement of the protection of Lake Kinneret water quality by removing pollutants and increase of soil fertility in the entire valley The HRP included the following components: Creation of a shallow Lake (wetlands) Agmon as a collector of nutrient rich drained waters from the valley canal system and River Jordan branch: average depth-35 cm, surface area 110 ha, with deeper parts and cruise route in the lake; total volume-app. $350,000 \mathrm{~m}^{3}$. Lake Agmon is located at 62 meters above sea level. The mean gauge of rain is $622 \mathrm{~mm}$ per annum and the multiannual average of temperature is $19.6^{\circ} \mathrm{C}$ : mean daily maxima and minima are $26.4^{\circ} \mathrm{C}$ and $14.3^{\circ} \mathrm{C}$ respectively. Renewal of drainage canals (90 Km) over the entire Valley directing nutrients rich drained waters inflow into the newly created shallow lake Agmon, and two optional outlets: 1) diverting out of the valley or 2) continue down stream to Lake Kinneret. A side branch of River Jordan to convey fresh river waters into Agmon and two diversion canals for peat soil drained waters: 1) "Canal Z" from the Northern part of the valley and 2) "Hula East"-from the Eastern peat soil blocks into Agmon. Placing a vertical plastic sheet (4 mm thickness) from soil surface to $4.5 \mathrm{~m}$ depth across the valley from East to West along $2.8 \mathrm{~km}$ attached to the southern bank of "Zero" Drainage Canal. The function of Lake Agmon is double: create a tourist attraction and to remove nutrients from the Kinneret external loads. The eco-touristic objective was overwhelmed success but nutrient removal was found to be insignificant. This paper is an attempt aimed at functioned analysis of the hydrological, chemical and climatological properties of Lake Agmon. After the Hula swamps drainage agricultural development was operated but desertification processes as well. Desertification does not necessarily overlap with droughts. Desertification is a process of soil fertility decline. Much of the world's population is located in deserts, where water resources are very limited. The populations in these dry lands do their best for food production under water limitation investing many efforts to save and /or transport water and therefore soil fertility become the limiting factor. Agricultural development is highly related to soil fertility (desertification) even if water supply is sufficient (no dryness) as occur in the Hula Valley. The HRP attempted to overcome the desertification processes. The design of the HRP aimed at consolidating the conflict between agriculture production, Kinneret water quality protection and nature conservation. Intensive research was initiated, agronomic methods were revised and implemented in a contract with the growers and the HRP program contributed to the stabilization of the Hula valley ecosystem and retarded the desertification process. The tension between farmers, water managers, nature preservation was reduced and collaboration came instead. The outcome of the HRP was renewal of an ecosystem, which has become a tourist attraction including rich biological diversity with approximately 300 species of birds (30 - 40,000 Cranes annually), 40 species of water plants, and 12 fish species. The new shallow lake Agmon ecosystem, became a tourism attraction. About 400,000 people are visiting Lake Agmon annually for recreation and birds (mostly Cranes) watching. However, it turned out that the amount of nitrogen and phosphorus as measured in the loads removal from the Kinneret, is not significant. Only in summer, occasionally, it has become meaningful in terms of phosphorus.

\section{Material and Methods}

The Agmon was constructed and filled with water during the summer of 1994. Seven Lake Agmon sampling stations, Inflows (Canal z, Jordan, Hula East) and outflows (the Southern Lake Outlet) were weekly sampled for chemistry and water discharge (Figures 1-4) [3]-[5]. The water discharge was measured by manual Flow-Meter at the inflows and outflows. The mass values were computed by multiplication of concentration by dis- 

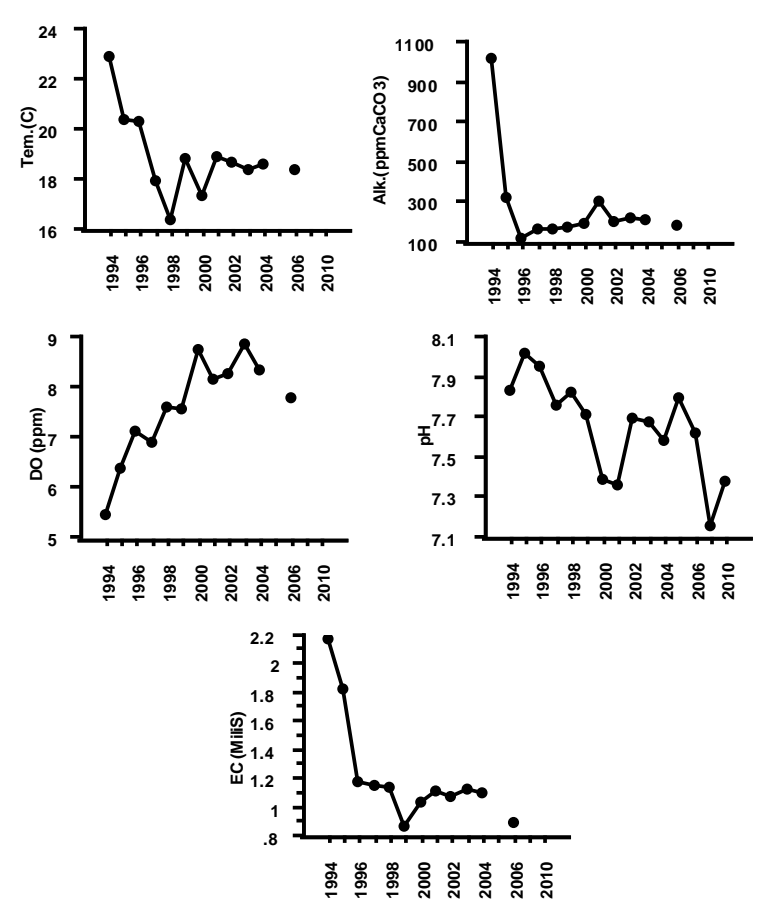

Figure 1. Annual averages (1994-2006) of physico-chemical parameters in Lake Agmon: Alkalinity (as ppm $\mathrm{CaCO}_{3}$ ) DO (ppm), temperature $\left({ }^{\circ} \mathrm{C}\right), \mathrm{pH}$, EC (electric conductivity (mS).
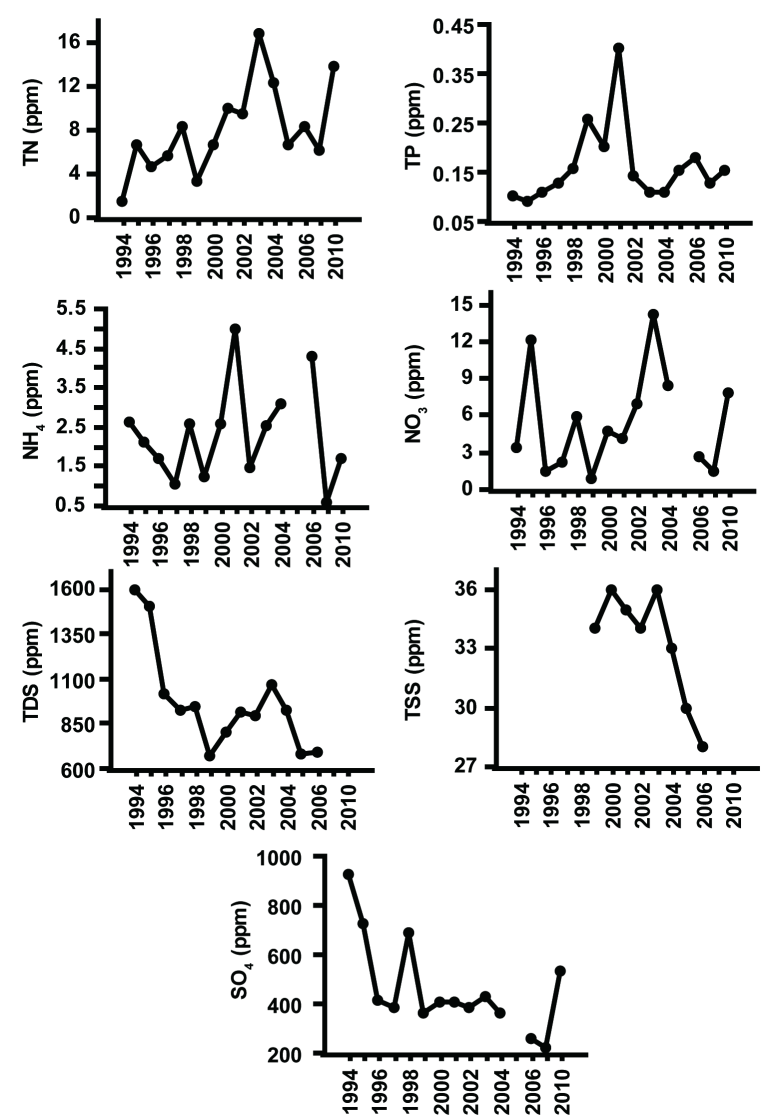

Figure 2. Annual averages (1994-2010) of nutrient concentrations (ppm) in Lake Agmon: TN, TP, $\mathrm{NH}_{4}, \mathrm{NO}_{3}, \mathrm{TDN}, \mathrm{TDP}$, and $\mathrm{SO}_{4}$. 

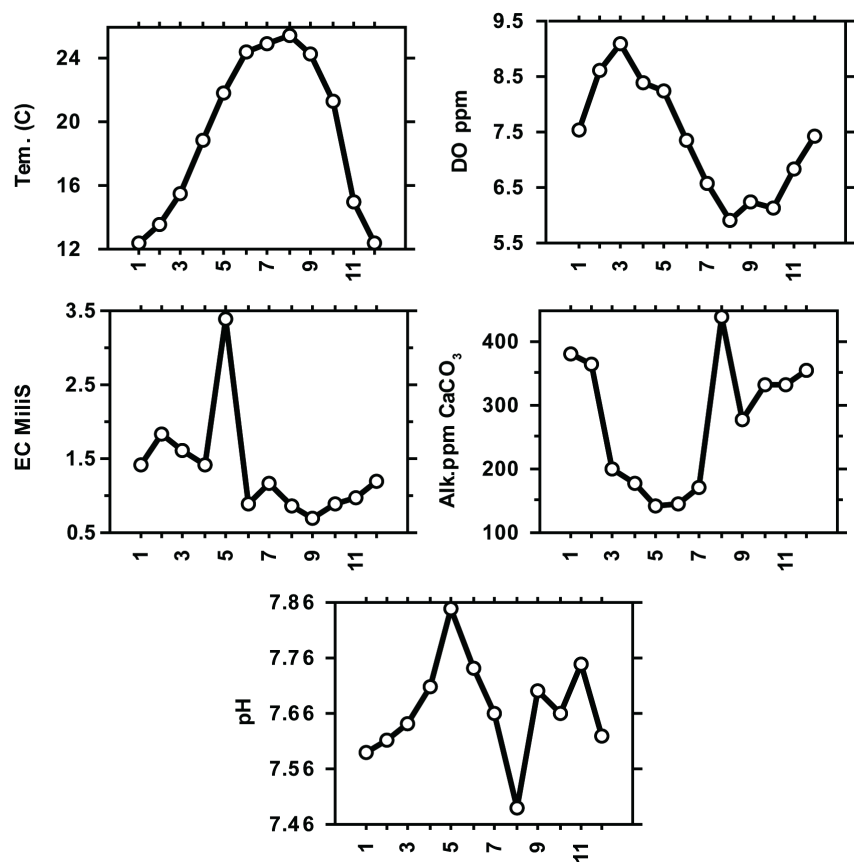

Figure 3. Monthly averages (1994-2006) of physico-chemical parameters in Lake Agmon: Alkalinity (as ppm $\mathrm{CaCO}_{3}$ ), $\mathrm{DO}$ (ppm), temperature $\left({ }^{\circ} \mathrm{C}\right), \mathrm{pH}$, EC (electric conductivity (mS)).
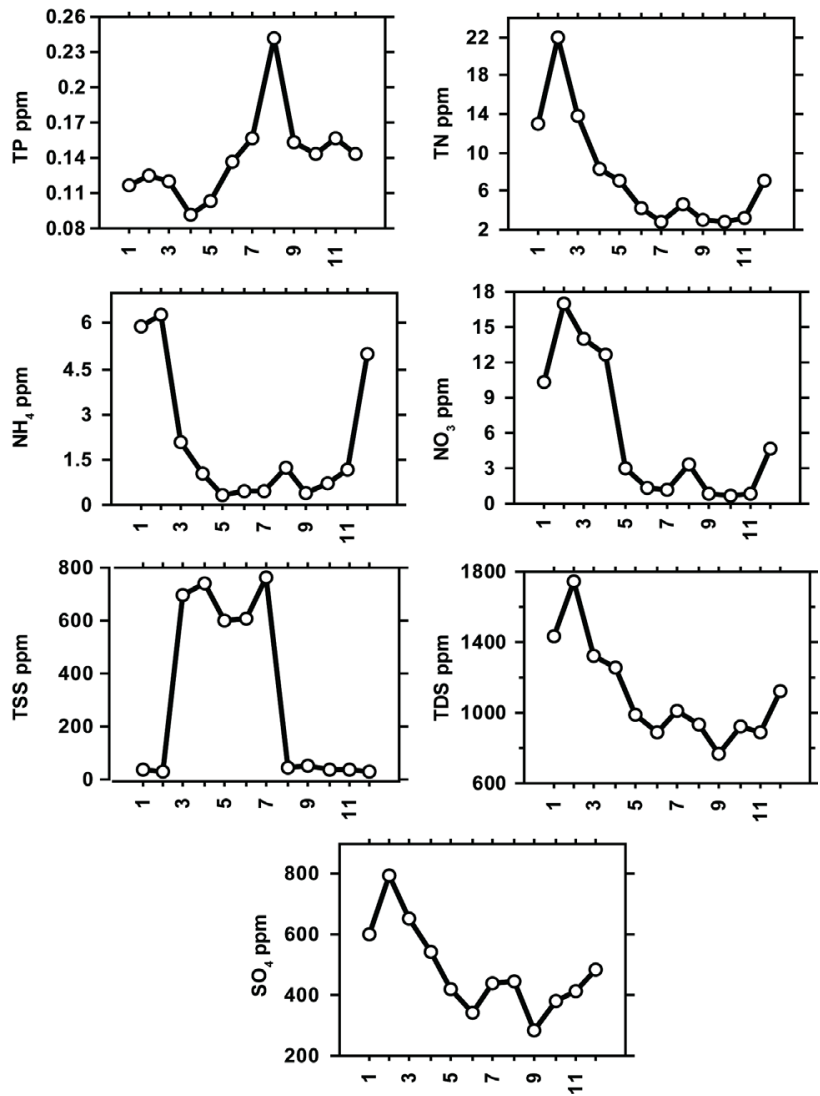

Figure 4. Monthly averages (1994-2006) of Nutrients in Lake Agmon (ppm): TP, TN, $\mathrm{NH}_{4}, \mathrm{NO}_{3}$, TSS, TDS, $\mathrm{SO}_{4}$. 
discharge and monthly averages were calculated. The chemical analysis procedures of nutrients are given in [4]. The values of infiltration (inflow and outflow) through the bottom were calculated by closing the hydrological balance. The water level of the Agmon was routinely (daily) monitored on a fixed plate and the lake volume is considered as $350,000 \mathrm{~m}^{3}$. Climatological data (2000-2014) of wind velocities and directions, and evaporation were taken from the Hula Project Data Center [3]-[6] in Migal and the Hula Project Annual Reports [4] [5] and precipitation from the Dafna Station in northern Hula Valley (Peres 1940-2014) (Figures 5-8). The entire period

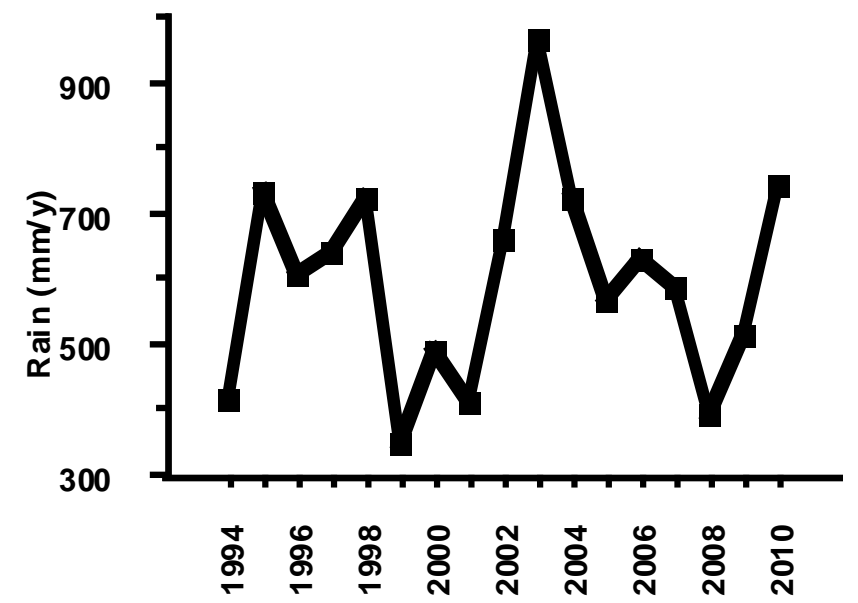

Figure 5. Annual precipitations (mm/y) in the Hula Valley (Dfna Station).
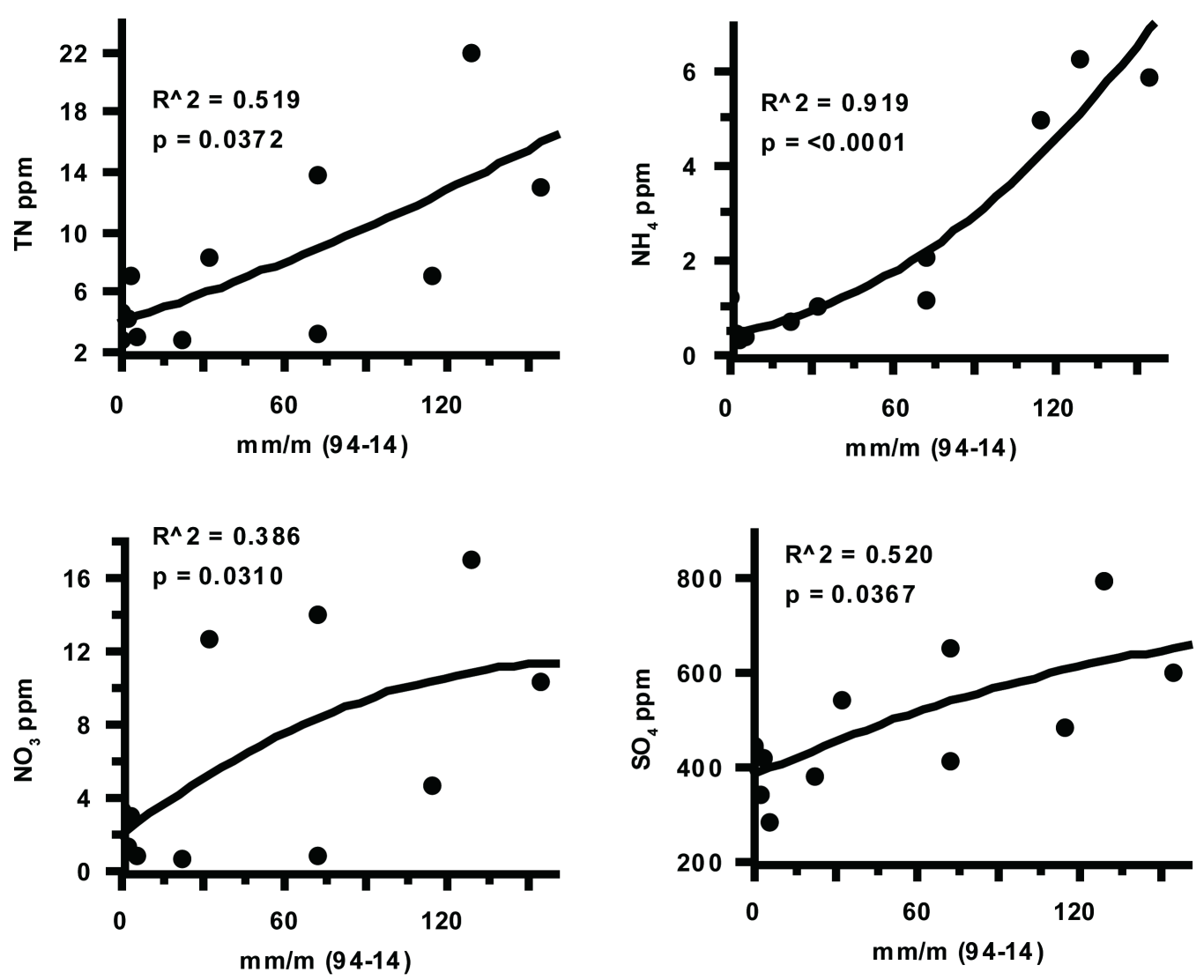

Figure 6. Polynomial regressions between monthly precipitations $(\mathrm{mm} / \mathrm{m})$ (averaged for 1994-2010) in the Hula Valley (Dafna Station) and total averages (1994-2010) of $\mathrm{TN}, \mathrm{NH}_{4}, \mathrm{NO}_{3}$ and $\mathrm{SO}_{4}$ in Lake Agmon (1994-2010). 

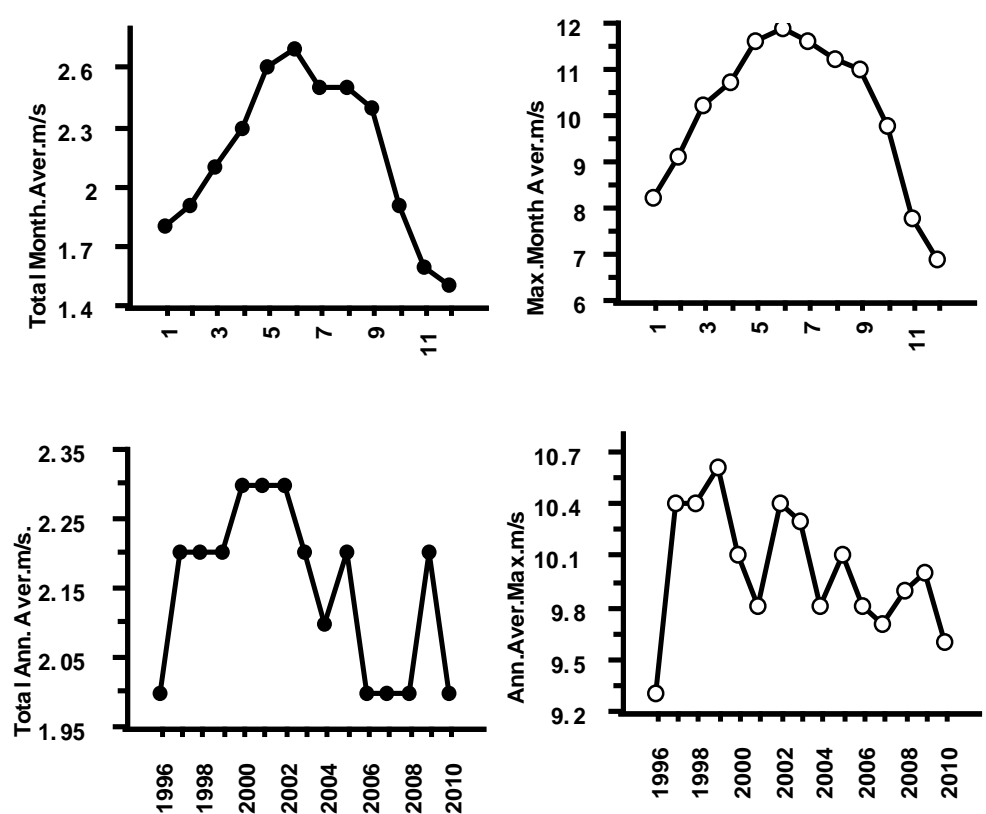

Figure 7. Left: Total annual (1996-2010; lower) and monthly (upper) averages of all wind velocities; right: Total annual (1996-2010; lower) and monthly (upper) averages of maximal wind velocities.

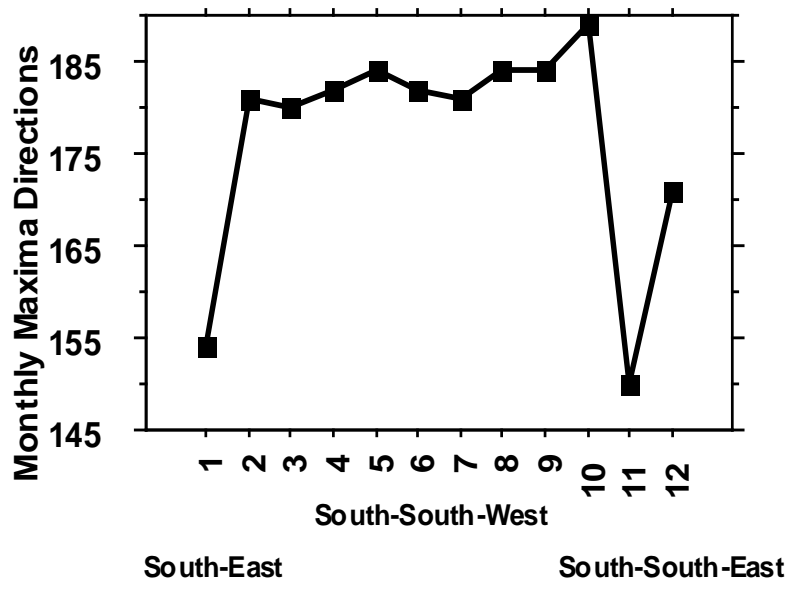

Figure 8. Monthly averages of directions of wind maximal velocities: $0^{\circ}=$ North, $90^{\circ}=$ East; $180^{\circ}=$ South; $270^{\circ}=$ West.

of sampling covered by this report is 1994-2010. List of measured parameters were (number of analyses of each parameter varied between 700 - 1690): Temperature, Alkalinity, Dissolved Oxygen, Electric Conductivity, Ammonium, Nitrate, Total Nitrogen, Total Dissolved Nitrogen, Total Phosphorus, Total Dissolved Phosphorus, $\mathrm{pH}$, Sulfate, Total Dissolved Solids, Total Suspended Solids.

Lake regions were determined as follows:

Region 1-North: Northern part including the reconstructed Jordan and Canal Z (peat drainage waters) inflows and the Islands area; Station Numbers: 44, 45, 48, 56, 57. The source of the bottom sediments is the organics left over residual of the swamps [7].

Region 2-East: including Hula East inflows (peat drainage waters) and nearby cruise canal; Station Numbers: $61,47$.

Region 3: South: including Agmon outflow; Station numbers: 46, 49, 55. The bottom sediments are highly mineral (mostly carbonates) due to the historical period when covered by the old Lake Hula [4]. 
Table 1. Regional total (1994-2010) averages of nutrient concentrations and physico-chemical parameters in Lake Agmon.

\begin{tabular}{cccc}
\hline Parameter/Region & North & East & South \\
\hline TSS (ppm) & 1009 & 984 & 626 \\
TDS (ppm) & 1222 & 1662 & 985 \\
$\mathrm{SO}_{4}(\mathrm{ppm})$ & 530 & 881 & 426 \\
$\mathrm{NO}_{3}(\mathrm{ppm})$ & 7.9 & 8.3 & 4.4 \\
$\mathrm{NH}_{4}(\mathrm{ppm})$ & 2.88 & 2.44 & 6.48 \\
$\mathrm{TN}(\mathrm{ppm})$ & 9.0 & 7.6 & 4.4 \\
$\mathrm{TP}(\mathrm{ppm})$ & 0.112 & 0.123 & 0.125 \\
$\mathrm{pH}$ & 7.6 & 7.6 & 7.9 \\
$\mathrm{EC}(\mathrm{mS})$ & 1.4 & 2.0 & 1.4 \\
$\mathrm{DO}(\mathrm{ppm})$ & 6.8 & 7.8 & 7.4 \\
$\mathrm{ALk} .(\mathrm{ppm} \mathrm{CaCO})$ & 326 & 150 & 253 \\
Tem. $\left({ }^{\circ} \mathrm{C}\right)$ & 19.3 & 21.0 & 18.9 \\
\hline
\end{tabular}

Table 2. Annual summary of hydrological balances of Lake Agmon (1999-2005): numbers are $10^{3} \mathrm{~m}^{3} / \mathrm{year}(\mathrm{mcm})$; WL change: $(\mathrm{I})$ = increase = additional loss; $(\mathrm{D})=$ decline $=$ additional gain.

\begin{tabular}{|c|c|c|c|c|c|c|c|}
\hline Source/Year & 1999 & 2000 & 2001 & 2002 & 2003 & 2004 & 2005 \\
\hline \multicolumn{8}{|l|}{ Gain } \\
\hline Jordan Inflow & 4.0 & 3.2 & 1.9 & 1.9 & 4.18 & 4.98 & 2.37 \\
\hline Canal Z Inflow & 3.2 & 1.5 & 6.0 & 6.9 & 5.04 & 7.75 & 4.57 \\
\hline Hula East Inflow & 1.24 & 0.43 & 0.5 & 0.5 & 0.79 & 0.55 & 0.31 \\
\hline Rain & 0.38 & 0.54 & 0.5 & 0.7 & 0.95 & 0.53 & 0.49 \\
\hline WL Decline & & (D) 2.53 & & (D) 0.20 & (D) 0.67 & (D) 0.92 & \\
\hline \multicolumn{8}{|l|}{ Loss } \\
\hline Agmon Outflow & 4.15 & 4.7 & 5.49 & 6.1 & 5.6 & 3.92 & 4.91 \\
\hline Evaporation & 1.7 & 2.1 & 2.3 & 2.3 & 2.7 & 2.12 & 2.19 \\
\hline Infiltration & 2.2 & 1.4 & 0.9 & 1.8 & 3.33 & 8.69 & 0.44 \\
\hline WL Increase & (I) 0.77 & & (I) 0.21 & & & & (I) 0.20 \\
\hline Total Gain & 8.82 & 8.20 & 8.90 & 10.2 & 11.63 & 14.73 & 7.74 \\
\hline Total Loss & 8.82 & 8.20 & 8.90 & 10.2 & 11.63 & 14.73 & 7.74 \\
\hline
\end{tabular}

\section{Results}

Results presented in Table 3 and Table 4 indicates an averaged annual (2000-2005) nutrients removal from the Kinneret loads by Lake Agmon as follows: Total Phosphorus-1.1 ton, Total Nitrogen - 34.7 ton, Nitrates-16 tons, Ammonium-5.4 tons, and Sulfates-1304 tons, of which only $\mathrm{SO}_{4}$ represent a possibly significant level of limnological impact within the Kinneret system and the others are not. It is suggested (Table 3 ) that Lake Agmon is a sink for TDP, TN, TDN, $\mathrm{NO}_{3}, \mathrm{NH}_{4}, \mathrm{SO}_{4}$ and Carbonates. Nitrogen is probably removed by de-nitrification and particulate sedimentation, $\mathrm{P}$ is incorporated by aquatic plants and $\mathrm{SO}_{4}$ associated with Ca$\mathrm{CO}_{3}$ is percipitated as Gypsum $\left(\mathrm{CaSO}_{4}\right)$. 
Table 3. Lake Agmon Hydrology: Annual inflow, outflow and balance (“In” minus "out”) (ton) of Lake Agmon nutrients (TP, TDP, TN, TDN, $\mathrm{NO}_{3}, \mathrm{NH} 4, \mathrm{SO}_{4}$ and $\mathrm{CaCO}_{3}=$ Alkalinity) (2002-2005).

\begin{tabular}{|c|c|c|c|c|c|c|c|}
\hline Year & In $(t / y)$ & Out (t/y) & Balance (t/y) & Year & In $(t / y)$ & Out (t/y) & Balance (t/y) \\
\hline & & TP & & & & $\mathrm{NO}_{3}$ & \\
\hline 2005 & 0.8 & 1.2 & -0.4 & 2005 & 19.4 & 3.3 & 16.1 \\
\hline 2004 & 1 & 0.4 & 0.9 & 2004 & 157 & 8 & 149 \\
\hline 2003 & 3.9 & 0.8 & 3.1 & 2003 & 83.1 & 50.9 & 32.2 \\
\hline \multirow[t]{2}{*}{2002} & 0.9 & 1.2 & -0.3 & 2002 & 56.1 & 13 & 43.1 \\
\hline & & TDP & & & & $\mathrm{NH}_{4}$ & \\
\hline 2005 & 0.2 & 0.2 & 0 & 2005 & 10.1 & 7.2 & 2.9 \\
\hline 2004 & 0.4 & 0.2 & 0.2 & 2004 & 35 & 0.3 & 34.7 \\
\hline 2003 & 0.4 & 0.2 & 0.2 & 2003 & 16.9 & 3.4 & 13.5 \\
\hline \multirow[t]{2}{*}{2002} & 0.5 & 0.2 & 0.3 & 2002 & 9.8 & 3.3 & 6.5 \\
\hline & & $\mathrm{TN}$ & & & & $\mathrm{SO} 4$ & \\
\hline 2005 & 38.1 & 27.3 & 10.8 & 2005 & 817 & 956 & -139 \\
\hline 2004 & 248 & 19 & 229 & 2004 & 3960 & 134 & 3826 \\
\hline 2003 & 95.8 & 68.5 & 27.3 & 2003 & 10898 & 1848 & 9050 \\
\hline \multirow[t]{2}{*}{2002} & 78.9 & 31 & 47.9 & 2002 & 1925 & 1763 & 162 \\
\hline & & TDN & & & & $\mathrm{CaCO}_{3}$ & \\
\hline 2005 & 34.7 & 21.6 & 13.1 & 2005 & 1409 & 577 & 832 \\
\hline 2004 & 227 & 12 & 215 & 2004 & 2877 & 972 & 1905 \\
\hline 2003 & 106.3 & 63.6 & 42.7 & 2003 & 2147 & 757 & 1390 \\
\hline 2002 & 67.2 & 22.4 & 44.8 & 2002 & 2178 & 793 & 1385 \\
\hline
\end{tabular}

Table 4. Annual Nutrient (TP-Total P, TN-Total $\mathrm{N}, \mathrm{NO}_{3}$-Nitrate, $\mathrm{NH}_{4}$-Ammonium, $\mathrm{SO}_{4}$ - Sulfate) loads (ton) removed from Lake Kinneret through the Lake Agmon outflow during 2000-2005.

\begin{tabular}{ccccccc}
\hline Nutrient/Year & 2000 & 2001 & 2002 & 2003 & 2004 & 2005 \\
$\mathrm{TP}$ & 1.3 & 1.6 & 1.2 & 0.8 & 0.4 & 1.2 \\
$\mathrm{TN}$ & 15.1 & 47.0 & 31.0 & 68.5 & 19.0 & 27.3 \\
$\mathrm{NO}_{3}$ & 5.4 & 15.6 & 13.0 & 50.9 & 8.0 & 3.3 \\
$\mathrm{NH}_{4}$ & 1.3 & 16.8 & 3.3 & 3.4 & 0.3 & 7.2 \\
$\mathrm{SO}_{4}$ & 1968 & 1153 & 1763 & 1848 & 134 & 956 \\
\hline
\end{tabular}

Sediments Re-suspension: The impact of Wind Velocity and Fetch Distance (distance over the water that wind blow to create Waves, Ripples or Micro Ripples moving in the same direction) on sediments re-suspension was widely investigated especially in shallow lakes [8]-[13]. Read et al. [8] analyzed the impact of wind fetch and velocity on Diffused Attenuation Coefficient (Kd), Wind Shear Velocity (U*), Convection Velocity (W*), and others in different lakes including small surface of water bodies (Agmon surface is 110 ha) and $\mathrm{Z}_{\text {mix }}\left(\mathrm{SML}_{\mathrm{S}}<\right.$ $1 \mathrm{~m}$. They concluded that both, convection and wind shear should be considered especially in small lakes. Convection has increasing importance for small lakes for the measurements of limnological parameters. Convection is dominant source of turbulence in small lakes due to the convectively derived turbulence. Consequently wind 
velocities $(\mathrm{m} / \mathrm{s})$ and directions in the Agmon region were measured $10 \mathrm{~m}$ above soil surface and analyzed (1996-2010): Monthly averages and annual averages for the entire period (1996-2010) of daily means are given in Figure 7. It has to be considered that the turbulence effect on the Agmon waters is mostly affected by high velocities of wind. Therefore, averages of monthly and annually of daily maxima were evaluated (Figure 7). It was found that those values were higher $(9.8-10.6 \mathrm{~m} / \mathrm{s})$ during 1997-1995 and seasonally $(10.2-11.9 \mathrm{~m} / \mathrm{s})$ during March-September. With regard to daily maxima of wind direction frequencies the following distribution was indicated (Figure 8): $0^{\circ}-90^{\circ}-173$ events; $90^{\circ}-180^{\circ}-605$ events; $180^{\circ}-270^{\circ}-1048$ events; $270^{\circ}$ $360^{\circ}-$ no events. Consequently, the dominant directions of maximal daily wind velocities is within the sector of $90^{\circ}-270^{\circ}$ (East-South-West).

Nutrient concentration Fluctuations: The temporal fluctuations (annual and monthly) (1994-2006) of physico-chemical parameters (DO, Temperature, Alkalinity, $\mathrm{pH}$ and Electric Conductivity) and nutrient concentrations are presented in Figures 1-4 and Rain precipitations in Figure 5. The data presented in those figures indicates the following conclusions: During years $(1995,1998,2002-2004$, and 2010) with high precipitations the nitrate concentrations in Lake Agmon were significantly (ANOVA: $\mathrm{p}<0.05$ ) higher and lower during droughts (1999, 2007, 2008). Moreover, in winter months (12, 1-4) $\mathrm{NO}_{3}$ concentrations were significantly (ANOVA: $\mathrm{p}<$ 0.05) higher. Spatial distribution of $\mathrm{NO}_{3}$ concentrations in Lake Agmon indicates high levels in the northern region due to drainage of peat soil into Hula East and Z canal. During the migration of Nitrates from north to south, $\mathrm{NO}_{3}$ concentration decline probably resulted in by de-nitrification. The seasonal (monthly) distribution of TP indicates high concentrations during summer months (6-12) and low in winter (1-5) (ANOVA: $\mathrm{p}<0.0001$ ). Nevertheless, the spatial distribution of TP within lake Agmon represent low differences between regions. Interestingly, temporal distribution (yearly) clearly indicates significant (ANOVA: $\mathrm{p}<0.0001$ ) variation between 1994-1998 and 1999-2001 periods. During recent periods after 1999 TP level in Lake Agmon is higher, probably affected by Crane population (20 - 40,000 per season) (Litaor et al. 2014; 2015). The annual fluctuations of TN indicates higher level during 2001-2004. The spatial distribution of TN emphasize the high contribution of Canal Z and Hula East conveying peat drainage waters. The seasonal (months) fluctuations of TN prominently (ANOVA: $\mathrm{p}<0.0001)$ represent high concentrations in winter $(12,1-5)$ and low in summer $(6-11)$. Suggestion is that it is affected by the peat soil flushing by rain water flux. With regard to Ammonium $\left(\mathrm{NH}_{4}\right)$ it is also clear that peat drained waters contribute high concentrations of this nutrient. ANOVA test indicated significant $(\mathrm{p}<$ $0.05)$ higher levels during rainy season $(12,1-3)$ probably from peat drainage sources. The $\mathrm{SO}_{4}$ dynamics prominently represent significant (ANOVA: $\mathrm{p}<0.0001$ ) low level in the Jordan waters which are not peat soil drained and all other types of water contain higher concentrations. Seasonal comparative ANOVA test between summer and winter resulted by significant $(p<0.0001)$ lower concentration in summer $(6-1)$ than in winter (12, 1-5). The annual fluctuations of total lake averages represent significant (ANOVA: $p<0.05$ ) low levels during droughts (2005-2008), in comparison with heavy rainy periods $(1995,1998,2010)$ whilst the high value for 1994 is probably due to the initial water filling. Moreover, Polynomial Regressions between monthly precipitations and TN, $\mathrm{NH}_{4} \mathrm{NO}_{3}$, and $\mathrm{SO}_{4}$ concentrations in Lake Agmon as averaged for the entire period of 1994-2010 represent significant relations (Figure 6). Due to increasing biomass of submerged plants DO concentration was elevated (Figure 1) as a result of enhancement of photosynthetic activity. Nevertheless increase of pH values are predicted to correlate with intensified photosynthetic activity but it is not presented by recorded data. Higher DO values in winter moths (Figure 3) are probably resulted by enhanced solubility of Oxygen in the winter colder temperatures. The higher EC values in winter months (Figure 3) are probably resulted by enhancement of TDS. Conclusively, it is clear that the Nitrogen and Sulfate originate in the peat soil and conveyed by water flushing.

\section{Discussion}

In previous paper (Gophen 2015) the dynamics and ranges of nutrient sources of Lake Agmon were described. The present paper is focused on the seasonal, spatial and temporal fate of nutrient influxes and internal changes within lake Agmon eco-system and climatological (precipitations, wind velocities and directions) conditions. Lake Agmon is a newly created shallow body of water which is a component of the reclamation system of the Hula Project (HRP) in the Hula Valley (Israel). The objectives of the HRP are aimed at Lake Kinneret water quality protection, and improvements of the hydrological, agricultural and eco-tourism service managements in the Hula Valley. Ten years of research and monitoring of the climatological, hydrological, nutrients and physico-chemical parameters are summarized and focus is giving to Nitrogen and Phosphorus. The degradation of organic matter originate from submerged vegetation is an internal P source and breaking of organic substances 
in the peat soil release bounded P which is flushed and migrate by rain drainage into lake Agmon [14] [15]. Peat soil Gypsum dissolution contribute sulfate which is transfer into Lake Agmon through drainage as well as Carbonates (Alkalinity) and partly re-precipitated as $\mathrm{CaSO}_{4}$ (Gypsum) onto the lake sediments.

Nutrients Mass Balance [1][2]: The Agmon system is activated as a Nitrogen sink by de-nitrification and particulate sedimentation and contributor of plant mediated Phosphorus. In the Jordan flows a stable composition of nutrients was documented but those of the peat drainage and the lake effluents represent higher level in winter and lower in summer. Very low level of anoxia in the upper most bottom sediments (7 - $8 \mu$ Molar sulfide concentration) was indicated at the southern part of the lake [7]. Negligible amounts of Nitrogen and Phosphorus are removed by the Agmon system from the Lake Kinneret budget. Nitrogen reduction in Lake Agmon is due to de-nitrification and sedimentation and $\mathrm{P}$ increase to degradation of aquatic vegetation. The merit of the newly created shallow Lake Amon is aimed at two major targets: 1) eco-tourism which is practically night-stay service site for 30 - 400,00 Cranes during November-March, stay, feeding and nesting of aquatic birds. 2) Hydrological Agricultural regulations for the entire Hula Valley. There are three major inflows into the Lake: Canal Z, Jordan and Hula East. The peat soil composition has no impact on the Jordan water quality whilst the two others are significantly affected. Nitrogen and Sulfate are weakly bounded to the peat soil substances and therefore easily flushed out by infiltrated water which conveys them into the lake. Nevertheless changes occur within the lake (Table 1): decline gradient was indicated from north to south for the concentrations of $\mathrm{SO}_{4}, \mathrm{NO}_{3}, \mathrm{TN}, \mathrm{TSS}$, TDS (EC) and DO. It is probably resulted by Gypsum precipitation (for $\mathrm{SO}_{4}$ ), de-nitrification (an-aerobic enhancement) and particles sedimentation (for $\mathrm{TN}, \mathrm{NO}_{3}$ and DO). The opposite (elevation) is due to Ammonium as a result of the de-nitrification process.

Wind effect (Figure 7 and Figure 8): The documented data on wind velocity and direction initiate probability that re-suspension activity is more intensive in the northern Lake Region and consequently contribute to enhancement of TSS, TDS, $\mathrm{SO}_{4}, \mathrm{NO}_{3}$ and TN concentrations in that region [12] [13].

Hydrological Regime: The hydrological regulation is precipitation dependant (Table 2, Figure 6): The rain gouge was high during 2002-2004 and consequently Jordan and Canal Z inflows, as well as high infiltration and Agmon Gain/Loss balance. Consequently, close dependence of Hydrological and precipitation regimes are indicated. Water accumulation in the Agmon is limited by linkage with ground water table in the vicinity which control agricultural managements. The Nutrient Mass Balances presented in Table 3 is also indicating the close relation between high rain gouge in 2002-2004, and the output of TP, TN, TDN, $\mathrm{NO}_{3}, \mathrm{NH}_{4}$, and $\mathrm{SO}_{4}$, as well as the total removal from Kinneret Loads (Table 4). Conclusively, the improvement of Kinneret Water quality protection is relay on climate condition (precipitation): when rain is heavy Kinneret water quality protection by Agmon system is more relevant.

\section{Summary}

The Construction (1994) of the shallow (wetlands) Lake Agmon, in the Hula Valley, Northern Israel, is aimed at improvement of the hydrologigal system in the agricultural land, establishing an eco-tourism in the valley, and pollutants removal from the external loads of the downstream Lake Kinneret. The newly renovated ecosystem of the Hula Valley was precisely monitored and interim report was documented and presented in this paper. Lake Agmon eco-system is very attractive and app. 400,000 visitors enjoy it annually, biodiversity significantly improved and agricultural income and returns increased. The hydrological and chemical properties of Lake Agmon indicate insignificant removal of pollutants from the Kinneret loads. The annual cycles of water and nutrient balances indicates precipitations and peat soil flushing as dominant impacts on the nitrogen and sulfate Agmon waters content and aquatic plant as phosphorus mediated contribution.

\section{Acknowledgements}

We give our warm thanks to E. Yasur and T. Nathanson for sampling and field assistance, to the MIGAL Laboratory Team of Analytical Chemistry, Ch. Milard for the Discharge measurements. The Project was funded by Jewish National Fund and water Authority to Migal.

\section{References}

[1] Gophen, M. (2015) Nitrogen and Phosphorus Dynamics in the Shallow Lake Agmon (Hula Valley, Israel). Journal of Ecology, 5, 55-65. http://dx.doi.org/10.4236/oje.2015.53006 
[2] Gophen, M. (2015) Management Improvement of the Agmon Wetlands System (Hula Valley, Israel) Aimed at Enhancement of Bird Populations and Kinneret Protection. Open Journal of Modern Hydrology, 5, 1-9. http://dx.doi.org/10.4236/ojmh.2015.51001

[3] Meron, M., Tsipris, Y. and Orlov-Levin, V. (1994-2015) Hula Valley Data-Base, Computerized Data Center-MIGAL: Climate, Agriculture, Discharge, Chemistry, Ground Water Table.

[4] Gophen, M., Ed. (1994-2006) Annual Reports, The Hula Project, KKL and Water Authority.

[5] Barnea, I., Ed. (2007-2014) Annual Reports, The Hula Project, KKL and Water Authority.

[6] Peres, M. (1940-2014) Precipitation Record, Dafna Station, Meteorological Service.

[7] Gophen, M. (2000) Nutrient and Plant Dynamics in Lake Agmon Wetlands (Hula Valley, Israel): A Review with Emphasis on Typha Domingensis (1994-1999). Hydrobiologia 00: 1-12.

[8] Read, J.S., Hamilton, D.P., Desai, A.R., Rose, K.C., MacIntyre, S., Lenters, J.D., Smyth, R.L., Hanson, P.C., Cole, J.J., Staehr, P.A., Rusak, J.A., Pierson, D.C., Brookes, J.D., Laas, A. and Wu, C.H. (2012) Lake-Size Dependency of Wind Shear and Convection as Controls on Gas Exchange. Geophysical Research Letters, 39. http://dx.doi.org/10.1029/2012GL051886

[9] Fee, E.J., Hecky, R.E., Kasian, S.E.M. and Cruikshank, D.R. (1996) Effects of Lake Size, Water Clarity, and Climatic Variability on Mixing Depths in Canadian Shield Lakes. Limnology and Oceanography, 41, 912-920. http://dx.doi.org/10.4319/lo.1996.41.5.0912

[10] MacIntyre, S., and Melack, M. (2009) Mixing Dynamics in Lakes across Climatic Zones. In: Likens, G.E., Ed., Encyclopedia of Inland Waters, Elsevier, Amsterdam, 603-612. http://dx.doi.org/10.1016/B978-012370626-3.00040-5

[11] Markfort, C.D., Perez, A.L.S., Thill, J.W., Jaster, D.A., Porte-Agel, F. and Stefan, H.G. (2010) Wind Sheltering of a Lake by a Tree Canopy or Bluff Topography. Water Resources Research, 46, W03530. http://dx.doi.org/10.1029/2009WR007759

[12] Ordonez, C.F., Perez, R. and dela Fuente, A. (2013) Experimental Study of flow and Diffusional Mass Transfer Coefficient across the Wate-Sediment Interface Determined by Wind Blowing an Extremely Shallow Lagoons. Proceedings of 2013 IAHR Congress 2013, Congress, Chengdu, Volume 6, Tsighua University Press, Beijing. 9 p. Conference Paper: $35^{\text {th }}$ IAHR.

[13] Fuente, de la A., Ordonez, C.F. and Perez, R. (2015) Diffusional Mass Transfer Coefficient at the Water-Sediment Interface for Wind-Induced Flow in Very Shallow Lagoons. Environmental Fluid Mechanics.

[14] Litaor, I.M., Reichman, O., Dente, E., Naftaly, A. and Shenker, M. (2014) The Impact of Ornithogenic Inputs on Phosphorus Transport from Altered Wetland Soils to Waterways in East Mediterranean Ecosystem. Science of the Total Environment, 473-474, 36-42. http://dx.doi.org/10.1016/j.scitotenv.2013.11.126

[15] Litaor, M.I., Barnea, I., Reichman, O. and Zohar, I. (2015) Evaluation of the Ornithogenic Influence on the Trophic State of East Mediteranean Wetlands Ecosystem Using Trend Analysis. Science of the Total Environment, 539, 231240. http://dx.doi.org/10.1016/j.scitotenv.2015.07.103 